\title{
The Development of Tourism Based on Local Wisdom in Indonesia
}

\author{
Ansir launtu, Chaerunnisa Rumianti, Patta Rapanna \\ (Lecturer STIEM Bongaya Makassar, at South Sulawesi Province
}

\begin{abstract}
This Type Of Research Through Kualitati Approach Of Phenomenology, As Results Showed That Tourism In The Recently Developed In The Various Dimensions Of The Purpose Of Such A Nature Tourism/Nautical Tourism, Cultural (Tangible: The Site, Religious Buildings, Temples, Historical Buildings, Traditional Buildings, Museums; Intangible: Send ratasik, Customs, Cultural Values), Culinary Tourism, Sport Tourism, Health Tourism, Tourism Education, Agro Tourism, Tourism, Religious Tourism, Etc, For It Requires The Development Of Tourism Policy Support Of Various Components I.e. The Elements of Government, Private Sector, Academia And The Public At Large.
\end{abstract}

Keywords-: Policy, Trade, Tourism, Development Wisdom.

\section{INTRODUCTION}

Tourism is an important sector in the development of the world economy. Even in Indonesia's tourism sector is the second largest foreign exchange acceptance of the sector after Oil-Gas. From the aspect of the cantonal Parliament, the tourism sector has a character (consumers /tourists must come to the site to consume products) provide opportunities and a very big contribution to the development of the region, open the isolation area and alleviation poverty. It promotes growth and development of the region's tourism and service centers spread across the Malay Archipelago well come within the urban/rural area urban, even remote areas in the Interior as well as in smaller islands.

Tourism is an activity that directly touching and engaging the public, so bring a variety of benefits against the local community and beyond. Even tourism in say has incredible energy, capable of making local communities experiencing developments in various aspects. Tourism has many benefits for society even for the country though. The benefits of tourism can be viewed from various aspects/facets i.e. tourism benefits in terms of economic, social, cultural, environmental and social reasons, the value of science, as well as opportunities and employment.

Indonesia is a country that is rich in places of interest to tourism; beautiful interior and friendly, towering mountains, beautiful beaches, ruins of historical and cultural interest, to nightlife in Jakarta and Bali, as well as his MICE tourism continues to grow. Its own tourism sector in Indonesia, is a promising sector. Currently, tourism is ranked as the fourth largest foreign exchange earner in Indonesia after oil and gas (oil \&amp; gas), coal, and oil palm. The Government through the Ministry of tourism
(Kemenpar) of the Republic of Indonesia is targeting tourism Indonesia are in large 30 positions at the global level. With the target, the Ministry of tourists calculated that in the year 2019 the tourism sector will contribute to the national economy by $15 \%$ as well as absorbing as many as 13 million labor force, with foreign exchange earnings amounted to Rp275 trillion .

Indonesia successfully welcomed almost 10 million foreign tourists who came to this country in the year 2015. However, this figure is much lower than the number of tourists who visited neighbouring countries Singapore (15 million) or Malaysia (27 million). Thus, what makes Indonesia losing competitiveness? According to data from the Central Bureau of statistics, foreign tourists to visit Indonesia per October 2016 is 1,040,651, a larger number than in October 2014, 825,818 foreign tourists. Foreign tourists visit this always increase from 2013 to 2014 $(8,802,129)(9,435,411)$, up to the year $2015(9,729,350)$. The visit of foreign tourists increased to Indonesia open wider opportunities to entrepreneurs of tourism industry, with growth in gross domestic product (GDP) amounted to $+5 \%$ and investment growth, there is an increasing demand for Hotels and condos (which combines the features of the apartments and hotels), and also places Conference and exhibition. Whether in its development, the tourism industry in Indonesia are experiencing constraints? And how the Government intervene in the matter related policies of tourism industry in Indonesia?.

Indonesia is experiencing a surge in ratings of 70 in 2013 , be 50 by the year 2015 , according to the Tourism Competitiveness Report \& Travel from the World Economic Forum. That is because the visit of foreign tourists increased very quickly, as well as national priorities against the tourism industry and infrastructure investments such as mobile phone networks that are increasingly accessible to the widespread air transportation.

\section{A. problem Statement \\ How does the local wisdom-based tourism} development in South Sulawesi

\section{REVIEW OF THE LITERATURE}

\section{A. Understanding Tourism}

According to Act No. 10/2009 about tourism, the tourism is a huge variety of tourist activities and is supported by a wide range of facilities and services provided at the community, employers, Government, and local governments. 
Koen Meyers (2009), tourism is an activity conducted by the while time from the original habitation to the goal with the reason not to settle or make a living but rather just to satisfy curiosity, spending time leisure or holiday as well as other purposes.

Suwantoro (1997), tourism is a temporary pullout process from a person or more to lai from outside his residence for a reason and not to undertake activities that generate money., James j. Spillane, tourism is travel activities with the aim to obtain pleasure, looking for satisfaction, kn improve healty know something $\mathrm{h}$, enjoy sports or breaks, perform tasks, and pilgrimage, Soekadijo (1996), tourism is full Characteristic in society, it included hotels, attractions, souvenirs, tour guide, transportation, travel agencies, restaurants and many others.,

\section{B. Public Policy}

Public policy often made without much dependence on economic reasoning. Economists often do not realize what is happening in the world of public affairs. As a result, both the quality of public decision-making and the role that economists play in it less than optimal (in Alicia h. Munnell, 1992). Public policy is something that is dynamic and complex instead of something stiff and dominated by the sheer formal power holders, but public policy back to the basic meaning of democratic. the policy of, by and for the public (the people ).

Michael e. Porter in Susilawati (2007) tells us that competitive advantage from each State is determined by how capable the country was able to create an environment that fosters the competitiveness of every actor in it. In the context of global competition, then the task of the public sector is building an environment that allows each of the principals of development able to develop themselves into the perpetrator-perpetrators are competitive. This environment can only be effectively created by the existence of public policy. Therefore, the best public policy is the policy that encourages every citizen to build community power saingnya respectively and not more and plunges into a pattern of dependency.

While Suharto ( in Susilawati (2007) stated that the policy (policy) at its core is the decisions or actions which directly regulate the management and distribution of natural resources, financial, and a human being for the sake of public interest, namely the people's lot, population, society or citizens. The policy in fact is the result of a synergy of compromise, or even competition among the various ideas, theories, ideology, and representing the interests of the political system of a country. Other definitions similarly expressed Nugroho (2008) in Susilawati (2007), that public policy is a decision that made the State Government, especially as the realization of the objectives of the strategy of the State concerned.

The stakeholders here are individuals, groups, or institutions having an interest against a policy. This policy can be a stakeholder of the actors involved in the formulation and implementation of policy, the beneficiaries as well as victims harmed by a public policy. There are three groups of key stakeholders primary, and secondary stakeholders (Suharto, 2007 in Yuli dkk, 2012). While the public policy process itself consists of three stages, namely the formulation, implementation, and evaluation (in Yuli dkk, 2012).

\section{Public Policy Transparency}

Public transparency is the principle that guarantees access or freedom for everyone to obtain information about the Organization of the Government, i.e. information about policy, the process and its implementation, as well as the results of the achieved. Assumptions can be formulated, more transparent public policy, which in this case is the Revenue Budget shopping area then the supervision carried out by the Board will be increased because the society is also involved in supervising the public policy (Yulinda and Lilik in Earn Rudianto, 2012).

Implementation of policies is a process implementing the policy decisions made by the individual/group or Government officials as well as private in order to achievement of the objectives outlined in the policy decisions that will affect the final results of a policy. With regard to the success of the implementation of the policy, Edward III (in Iskandar, 2012:90) suggests four factors that affect the implementation of the same policies or whether a policy is successful (1) communication (2) resources (3) Dispositions/Attitudes (4) bureaucratic structure (Supianto, 2012).

\section{Local Wisdom}

Local wisdom is the truth that has become a tradition in the area. Local wisdom has a high content of life value and worth constantly dug up, developed, and has been preserved as the antithesis of cultural and social change or modernization. Local wisdom of past cultural products that are continuously being made in order to handle life, although local value but the value that is contained in it is deemed very universal. Local wisdom is formed as the cultural superiority of the local community as well as the geographical conditions in the broad sense.

Local wisdom is seen very worth and has its own benefits in people's lives. The system was developed because of the need to live up to, maintain, and sustain a life according to the situation, condition, abilities, and values lived in the communities concerned. In other words, local wisdom that later became part of their way of life which arif to solve all life's problems they face. Thanks to their local wisdom can sustain life, even can develop in a sustainable way.

\section{RESEARCH METHODS}

Qualitative research approach through kind of Phenomenology. 


\section{DISCUSSION}

\section{A. Local wisdom-based tourism development in Indonesia}

Tourism is traveling from one place to another, temporary done individually or as a group, to find a balance or harmony and happiness with the environment dimension in the social, cultural nature and science. Thus the notion of tourism appears to be in among the experts have different opinions between the one with the other to look at the side of his views regarding the respective tourism it self. understanding tourism according to Act No. 9 of the year 1999 , is everything related to tourism, including business objects and tourist attraction as well as the efforts related to the Organization of tourism.

Thus tourism include: (1) all activities that are associated with the trip, (2) the Concession object and tourist attraction such as: tourism, recreation park, the historical heritage, museums, art and cultural performances, reservoirs, tata the life of the community or which is natural: the beauty of the Park, volcanoes, lakes, beaches, (3) Business services and means of tourism: tourism businesses (tour operator, travel agent, tour guide, conventions, trips incentives and exhibitions, tourism, consulting, impresariat tourism information), business tourism facility consisting of: accommodation, restaurants, bars, tourist transport. Tourism experts provide an understanding of tourism are a number of relationships and the resulting symptoms of residence foreigners, provided that their residence is not causing the onset of residence as well as the efforts temporary or permanent work-seeking efforts as full.

While the notion of tourism is anything related to the Organization of tourism (Act No. 9 of the year 1990), meaning that all the activities and Affairs of that had to do with the planning, arrangements, supervision of tourism well done by the Government, the tourism as well as the community.

According to the experts that the definition of tourism is a (activity) of one's journey from the place of origin to a place/environment with different environmental conditions of its origin to a specific destination such as recreation, business, hospitality/ family visits or other purposes which takes more than 24 hours, as well as utilizing elements of supporting/ancillary facilities such as transportation, accommodation, restaurants, entertainment, souvenirs and so on.

That's why the recent tourism developing in the various dimensions of the purpose of such a nature tourism/nautical tourism, cultural (tangible: the site, temples, religious buildings, building history, traditional buildings, museum.

Therefore, when we talk about tourism, it will not escape the talk about "perpetrators of activity, timing, goals and purpose as well as the availability of these supporting elements, something travel (travel)". An understanding of the elements of Tourism will point us to an understanding of what being a component of the development of tourism when we want to make it as an activity that gives benefits to the country and society, and what direction policies that should be taken against the development to an Indonesiatourism-and the world. It should be noted also that Tourism can not stand on its own because tourism is a multi dimensional activities, activities related to other elements such as political, economic, social, cultural, legal, and societal dimensions including defense and security others.

\section{B. The policy Provided in encouraging Tourism}

Transport is the sector that largely determine the success of the development. because of functioning transport bridge between the regions to each other, separated by distance. Encouragement of the development of transport very expected to give a positive impact against the activities of the community, such as providing the smooth mobility of the community as well as ensuring the safety of travel. The Government has an obligation to draw up planning and formulating policies, control, and supervise the embodiment of transportation in Indonesia. In accordance with the provisions of the 2005 Year 49 Number of Ministers of transportation system National Transportation materialize aims at effective and efficient support and simultaneously move the dynamics of human mobility, enhance the development of goods and services, help create a steady national distribution pattern and dynamic region, and support the development of more established development life of society, nation and State in the framework of the realization and improvement of relationship insights archipelago International.

The Government has been giving the Ministry of transport to the community, but the waiter did not facilitate passengers entirely. Call it the train transport commuter line. The company has provided convenience for the public, such as ticket prices are affordable as well as time travel that fast. However, the ease it was not supported by other facilities. Frequent occurrence of interference signals make the train ride being distracted, the travel time travel become longer as well as buildup of passengers at each station.

This facility is not fully executed with such support, the lack of security or other transportation for decisive action that has no right of entry had the Trans Jakarta buses make many other vehicles entered into the Trans Jakarta. Same problem on two banyanya the transport of damaged tool so make inconvenience for passengers, one of them an air conditioner. A broken air conditioner makes the air circulation is not smoothly that causes crowded, plus this is a transportation devotees.

\section{Component development and tourism development}

The first and main components of the development of tourism is environmental, natural resources and social culture; This component is the basic potential is already available and is owned by a region/area and communities, for example a beautiful natural panorama, lakes, natural forests, plantations and vast farmlands, weather and a cool climate, site, art and legends culture, customs and life of the unique community-specific, local wisdom. This component 
requires attention, handling and creativity into products or commodities that can drive the economy of the community.

The second component is a component support must be available in sufficient quantities and quality, according to needs, namely the transport elements (accessibility) land, sea, air and other infrastructure; accommodation and catering, elements of institutions, institutional and human resources; and other support facilities.

The third component is the marketing activities "marketing" over major components and supporting components, linking producers and consumers, this component such as travel agent, tour operator, travel media, including the associated information such as media print, television, the internet is also a tourism information centres. This component into a kind of observer supervisor will be good and bad objects and the Ministry of tourism in a tourist destination. In order of development and the development of tourism.

These three components are not stand alone but having attachment and connectedness very closely, especially in the era of globalization and free trade era. If seen more thorough process dependencies are reflected as follows: when the Tourists will do the excursions (tourism) then the first required infrastructure/transportation (airport/airplane, road/rail; Terminal, Transfer,), during the travel need of agricultural/animal husbandry/fishery; at the destination (destination) are needed, consumption and

\begin{tabular}{|c|c|c|c|c|c|c|c|c|}
\hline Bulan & $\begin{array}{l}\text { Tourist } \\
2013\end{array}$ & Arrivals & $\begin{array}{l}\text { Tourist } \\
2014\end{array}$ & Arrivals & $\begin{array}{l}\text { Tourist } \\
2015\end{array}$ & Arrivals & $\begin{array}{l}\text { Tourist } \\
2016\end{array}$ & Arrivals \\
\hline January & 614,328 & & 753,079 & & 723,039 & & 814,303 & \\
\hline February & 678,415 & & 702,666 & & 786,653 & & 888,309 & \\
\hline March & 725,316 & & 765,607 & & 789,596 & & 915,019 & \\
\hline April & 646,117 & & 726,332 & & 749,882 & & 901,095 & \\
\hline May & 700,708 & & 752,363 & & 793,499 & & 915,206 & \\
\hline June & 789,594 & & 851,475 & & 815,148 & & 857,651 & \\
\hline July & 717,784 & & 777,210 & & 814,233 & & $1,032,741$ & \\
\hline Augus & 771,009 & & 826,821 & & 850,542 & & $1,031,986$ & \\
\hline September & 770,878 & & 791,296 & & 869,179 & & $1,006,653$ & \\
\hline October & 719,900 & & 808,767 & & 825,818 & & $1,040,651$ & \\
\hline November & 807,422 & & 764,461 & & 777,976 & & & \\
\hline December & 766,966 & & 915,334 & & 913,828 & & & \\
\hline Total up & $8,802,129$ & & $9,435,411$ & & $9,729,350$ & & & \\
\hline
\end{tabular}

entertainment Lodging (hotels, restaurants, pubs-EntertainEvent), the availability of souvenirs, MICE (meeting, incentive, conference, excebishi), a goal or a tourist attraction, as are human resources ( business / perpetrators / tourism industry workers who quality and certified). Thus tourism is a long series of various activities that move "simbiose mutualistis".

As such Tourism it has system, tourism is the sustained by tourism businesses, communities and Governments in order to meet the wants and needs of travelers. Tourism system (One Stop Services for Tourism) consists of sub system Destinations, Travel system, the market system and marketing system today, Indonesia's tourism sector contribute to approximately $4 \%$ of the total economy. In the year 2019, the Government of Indonesia would like to increase this figure is doubled to $8 \%$ of GDP, an ambitious of destination (perhaps overly ambitious) which implies that within the next 4 years, the number of visitors increased to two fold into approximately 20 million. In order to achieve this goal, the Government will focus on fixing Indonesia's infrastructure (including the infrastructure of information and communication technology), access, health and hygiene \& also improves online promotional campaign (marketing) in overseas. The Government also revised the visa free access policy in 2015 (for further explanation, see below) to attract more foreign tourists. overall efforts made in a systematic, integrated and

Table 1. The visit of foreign tourists in Indonesia, 2013-2016 


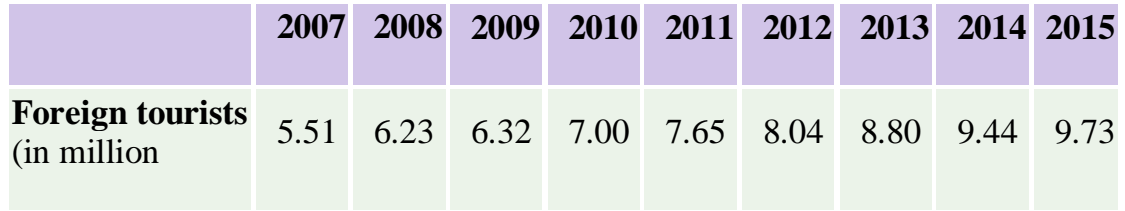

Resources : BPS

Table 2. The visit of foreign tourists in Indonesia, 2007-2015

In the Travel Tourism Competitiveness Report \& from the World Economic Forum, that's "measuring a number of factors and policies that allow for sustainable development of the sector of travel tourist \&, which in turn, contributes to the development and power competitive country, "Indonesia's ranking jumped from 70 in the year 2013 be ranked 50 in the year 2015, an amazing progress. The jump was caused by the rapid growth of foreign tourist arrivals to Indonesia, a national priority for the tourism industry and infrastructure investments (e.g. mobile phone networks now reach filmed the area in this country, and air transport has been expanded). The report stated that the advantage competitiveness of Indonesia is at competitive prices, the wealth of natural resources (biodiversity), and the presence of a number of cultural heritage location.

Even so, the report also stated that Indonesia did not give enough emphasis on environmental sustainability (deforestation resulted in debt and jeopardize a number of rare species, while only a few of the waste water processed). The report also mentions concerns about safety and security worries, especially business losses due to terrorism. Other worries is because Indonesia lagged behind compared to Singapore (ranked 11th), Malaysia (ranked 25th) and Thailand (ranked 35) in India Travel Tourism Competitiveness Report \& 2015.

The lack of a proper infrastructure in Indonesia poses problems, not only because this greatly increases the cost of the logistics of making less attractive investment climate but also reduces the smooth travel for tourism. Infrastructure in Bali and in Jakarta is pretty decent (except for traffic jams exceptionally large) but outside of Bali and Jakarta most of the infrastructure in the country is less feasible, especially in eastern Indonesia due to lack of facilities, ports, roads, and hotels. The lack of connectivity within and between islands means there are a large number of regions in Indonesia with tourism potential which cannot be seen easily.

\section{Indonesia's Tourism Industry Opportunities}

With the increase of the number of foreign tourist arrivals (both tourists as well as foreign businessmen) combined with GDP growth of $+5 \%$ and investment growth, there is an increasing demand for hotels and condos (which combines the traits the apartments and hotels), and also places Conference and exhibition. When the target Government welcomed 20 million foreign tourists in 2020 is reached then there is a great need for the hospitality industry of the country. The more homogeneous the lifestyle of society due to globalization, the more robust the society's addiction to values that are more like religion, art and literature. Likewise, from the perspective of local, as the world grows increasingly homogeneous then we increasingly appreciate the traditions that come from within. Local value addition is able to inspire the growth of local wisdom (local in digeneus), on the one hand grew to be the values of life that give meaning to the lives of their fellow man and interaction. Strategic value local culture has inspire different areas to develop the potential of tourism development in the locality. With a variety of the above considerations, then the development of tourism must not marginalize local culture. Therefore need to be set out in the development of tourism which coincided with the development of culture and copyright, taste. This idea is developed based on the assumption that the construction of the object based on the development of society and culture. Then what is the solution? Because of the still low level of our awareness of how important tourism is local wisdombased solutions to develop tourism based on local wisdom:

- Socialize to related parties such as the Minister of tourism is how important the local wisdom-based tourism, karna's prediction that in the future will come ketertariakan community-based local tourism will be it's very height.

- Invites those who would like to join either as donors or similar to join us.

- $\quad$ place the Observations which will be developed in this regard, we come and socialize to locals how Interestingly the tourism in polishing with local wisdom.

- Look for sponsor who want to embody and promote this idea.

$>$ All it aims to

- Make excellent Indonesia Tourism competitiveness

- The reduction of the impact of globalization and modernization so as not to remove and scrape the local wisdom that we have

- Introduce local wisdom, that Indonesia is not easy in the claim by other countries 
- $\quad$ Bearing the name of Indonesia in the eyes of the world in tourism

The tourism sector as the mainstay in Indonesia which must be supported by other sectors, particularly infrastructure and transportation. With adequate infrastructure management, the availability of qualified human resources in the tourism sector, as well as intensive and which marketing activities are well planned, what the President is saying Jokowi is not something that is impossible to earned. Foreign tourists visit destination by 20 million in 2019 the pun is not just a mere dream. Primary capital we already have. Indonesia had a variety of natural beauty and cultural wealth, spread from Sabang to Merauke, from Miangas (North Sulawesi) to Rote (East Nusa Tenggara). Cultural tourism is one of the extraordinary wealth that we have and this can bring in foreign exchange for the country.

Cultural tours include a variety of activities such as watching art performances, see the cultural festival, visit a traditional settlement with custom homes, visit museums, and visit the site of cultural heritage the heritage of the past or regular referred to as a tourist heritage (heritage tourism). According to a number of the study, in the future, the cultural attractions are increasingly attractive to the foreign tourists.

Many other regions in Indonesia that are indeed not less Interestingly with Yogyakarta or Bali. These areas could be developed into a cultural tourist destination which could generate foreign exchange. It certainly should start with marketing communication activities that are more intensive and effective efforts are continuously made to improve the quality of tourist attraction in every destination. The attention of the Government is the most important thing. The reason, a lot of impact or positive value that can be gained from a cultural tour visits. In addition to the one sector that could be foreign exchange, tourism-based elections caused culture thus can become social forces to improve cross-cultural understanding, motivation for preserving the culture and environment, can even strengthen our spirit nationality. More than that, through cultural tourism that tourists, especially tourists, can learn about the history, culture, local art even. From there they can understand and explore the dynamics of cultural development, local wisdom, and copyright, the works, and the intention of a society.

It's just that, a variety of stories and wisdom from history, culture, and the arts contained within the cultural attractions are to be delivered in a way that draws so memorable for tourists. The various techniques of delivery information about the values that are contained in a cultural or tourist attraction called natural interpretations. Interpretation can be done by a tour guide through the information boards and leaflets, through a written description of the objects are on display in a museum, electronic media, even with a more interactive way, using digital media. The same thing also applies to other cultural tourism, such as sites of cultural heritage, places of worship, as well as traditional housing. Tourist attractions like it should come with a competent guide or detailed information about the venue. It could be delivered directly by the guide or through the medium of an interesting interpretation of either interpretation panels or leaflets. History of Muarajambi Temple area in Jambi province, for example, turns out to have a very significant role in the development of Buddhism because it became a place to learn Sanskrit for Tibetans before they continue the journey to Nalanda in India to study Buddhism. This shows how its strategic geographical position the archipelago in the past, and it's become our excellence. In Java, from the history of Borobudur and Prambanan Temple, we can trace the attitude of religious tolerance that was been practised since the first.

\section{CONCLUSION}

The Setup and maintenance of tourist objects need to be improved both in terms of quality or quantity. A more professional management principles to all cultural attractions, update techniques and media interpretation, as well as the involvement of travellers and the community in preserving culture, is the assertion that can't be considered one eye.

\section{BIBLIOGRAPHY}

[1]. N Deputy, Sjarifuddin. Implementation of Sectoral Policies in the development of Sustainable Tourism from the Setup Persfektif space.

[2]. Bakry Aminuddin (2010), "education policy as a public policy", Journal of MEDTEK, Volume 2, number 1, April 2010.

[3]. Nusantara Astina, i. k. 1999. Geography Of Tourism. Poor: State University Of Malang.

[4]. Rohaedi. 1986. Kepribadian Budaya Bangsa (Local Genius). Jakarta: Pustaka Jaya.

[5]. Central Bureau of Statistics Selayar Islands Regency. "Profile of Selayar Islands Regency Area." Selayar: BPS, 2009.

[6]. Cholisin, M.Si \& Nasiwan, M.Si. 2012. Dasar Dasar Ilmu Politik. Yogyakarta: Ombak.

[7]. The Central Bureau of Statistics. 2015. In Toraja Regency numbers. Rantepao: BPS Toraja Utara. Belawati, T, dkk. 2003. Pengembangan Bahan Ajar. Jakarta: Pusat Penerbitan Universitas Terbuka.

[8]. Tourism, arts and culture. Regional Tourism Development Master Plan (RIPPDA) The Selayar Islands Regency. Selayar Islands: DISBUDPAR, 2008.

[9]. Idris, Supardi. Potensi Wisata Selayar. 2011.

[10]. The Office of tourism and culture of Toraja. 2015. Appeal of Toraja tourist attractions Utara. Rantepao: Arsip.

[11]. The Office of tourism and culture of Toraja. 2015. The details of the reception of the Toraja tourist attraction North of the Year 2014.

[12]. Nyoman, S. Pendit. The Science Of The Tourism As An Introduction To Prime. Jakarta: Pradnya Paramitha, 1994. 
[13]. Robert E. LUCAS, Jr. (1988), "On the Mechanics of Economic Development", Journal of Monetary Economics 22 (1988) 3-42. North-Holland.

[14]. Thorvaldur Gylfason (2001), "Natural resources, education, and economic development", European Economic Review (2001).

[15]. JoAnn C. Carland dan James W. Carland (2004), "Economic Development: Changing the Policy to Support Entrepreneurship", Submitted to the Association for Small Business and Entrepreneurship, Western Carolina University 2004.

[16]. Prof. Shailendrakumar Uttamrao Kale (2004), "Global Competitiveness: Role of Supply chain Management", Conference on Global Competition \& Competitiveness of Indian Corporate, IIMK 2004.

[17]. Paturusi, Syamsu Alam. The influence of Tourism Spatial Pattern against the traditional Balinese. Bandung: ITS, 1985.

[18]. Solanki, Cecep Eka. 2010. Local wisdom applied to Society in coping with the disaster. Jakarta: Wedatama Widia literature.

[19]. The Environmental Study Center UNHAS. "Socioeconomic and Environmental Studies in the Coastal Area and the sea." Makassar HASANUDDIN UNIVERSITY, PSLH: 1997.

[20]. Jess Benhabib, Mark M. Spiegel (1994), "The role of human capital in economic development Evidence from aggregate cross-country data", Journal of Monetary Economics 34 (1994).

[21]. Michael E. Porter (2000), "Location, Competition, and Economic Development: Local Clusters in a Global Economy", Economic Development Quarterly, Vol. 14 No. 1, February 2000 15-34.

[22]. Septina Flattened (2008), "Factors Affecting the economic development Gap Between regions in West Java 1996-2006 Period", Agricultural Economics Courses and resources Faculty of agriculture Bogor agricultural University 2008.

[23]. Sedarmayanti, 2014. Build and develop the culture and tourism industry (Potpourri writings of tourism). Bandung: PT Refika Aditama.

[24]. Sedyawati, Edy. 2006. The culture of Indonesia, the study of the archaeology, art, and history. Jakarta: Raja Grafindo Persada.

[25]. Sumarmi. \& Ach. A. 2014. Environmental Geography-Based Local Wisdom. Malang: Aditya Media Publishing.

[26]. Sunaryo, Bambang. 2013. the development policy of Tourism Destinations (the concept and its application in Indonesia). Yogyakarta: Media Gava.

[27]. Yoeti, Oka A. Introduction To The Science Of Tourism. Jakarta: Pradyana Paramita, 1996.

[28]. Simatupang Pantjar (2011), “Analisis Kebijakan: Konsep Dasar Dan Prosedur Pelaksanaan (Policy Analysis: Basic Concept And Procedures)", Prosiding Seminar dan Ekspose Teknologi Hasil Pengkajian BPTP Jawa Timur ISBN 979-3450-04-5.

[29]. Mariana Dede (2010), “Otonomi Daerah Dan Inovasi Kebijakan”, governance, Vol. 1, No. 1, November 2010.
[30]. Kuswandi Aos (2005), "the readiness of the Apparatus of Government in the implementation of Regional Autonomy In the areas of community service (the study of the implementation of Act No. 32/2004 in the town of Bekasi)", Journal of Madani Edition I/May 2005.

[31]. Werimon Samson (2005), "the influence of public participation and transparency of the public policy of the relationship between Knowledge of the Board about the budget With Financial Oversight Areas (GRANT) (Empirical Study in Papua Province)", master of Science degree Courses Accounting graduate programs University of Diponegoro November 2005.

[32]. Rofiuddin Mohammad (2012), "analysis of financial performance Area on the island of Madura, East Java province in the autonomous region of the year 2005-2009", publication of the journal of the Faculty of Economics University of Muhammadiyah Surakarta 2012.

[33]. Maulida Elza Pearl (2009), "an analysis of the sector's Competitiveness and potential Base Tourism Tasikmalaya Regency Post-war Autonomous Regions", Department of Economics, Faculty of Economics and management of Bogor agricultural University 2009.

[34]. Ranteao: Arsip. Nugroho, I. 2011. Ekowisata dan Pembangunan Berkelanjutan. Yogyakarta: Pustaka Pelajar.

[35]. The Republic Of Indonesia. "The legislation of the Republic of Indonesia No. 10 Year 2009 About Tourism." Bandung: the image of the Umbara, 2010.

[36]. Rosidi, Ajip. 2011. Local wisdom in perspective of the Sundanese culture. Bandung: The Direction Of The Main Book.

[37]. Rudiyanto Earn (2012), "the influence of the knowledge of the Board's financial Oversight Areas Against Tentanganggaran (GRANT), 